ORIGINAL ARTICLE

\title{
Job contentment among medical doctors: Warr-Cook-Wall questionnaire based study at an MTI based Tertiary Care Hospital.
}

\author{
Muhammad Usama ${ }^{1}$, Umair Toqueer ${ }^{2}$, Attiya Nasir Siddique ${ }^{3}$, Sana Khan ${ }^{4}$, Muhammad Basharat ${ }^{5}$, Anila Riyaz ${ }^{6}$
}

Article Citation: Usama M, Toqueer U, Siddique AN, Khan S, Basharat M, Riyaz A. Job contentment among medical doctors: Warr-CookWall questionnaire based study at an MTI based Tertiary Care Hospital. Professional Med J 2022; 29(2):251-257.

https://doi.org/10.29309/TPMJ/2022.29.02.6436

ABSTRACT... Objective: To determine job satisfaction level of doctors working at Ayub Teaching Hospital and correlate it to factors that affect job contentment with the help of a standardized tool. Study Design: Cross-sectional Analysis study. Setting: Ayub Teaching Hospital, Abbottabad. Period: First Two Weeks of December, 2019. Material \& Methods: A selfadministered online questionnaire was designed on Google Forms and was used to collect data from the doctors working at the aforementioned facility for more than three months. Data regarding various sociodemographic and professional characteristics as well as respondents' views about their job as per Warr-Cook-Wall scale were noted. Pearson's Correlational analysis, student's t-test and one way ANOVA were applied for data analyze. Results: Among a total of 176 doctors, mean Job Satisfaction Score (JSS) was $37.56 \pm 13.35$, which is below the neutral level, showing overall discontent and only 72 (40.9\%) respondents were actually satisfied with their jobs. Highest content was noted for "Colleagues \& fellow workers" and "Amount of Responsibility", among the scale's parameters. Whereas doctors were least satisfied with their "income". Salary had a weak but statistically significant correlation with satisfaction score. Those working at basic medical sciences departments were more satisfied $(p=0.006)$ and so were permanent employees $(p=0.024)$. Professors were significantly more content $(p=0.005) .71 \%$ of the doctors would like to be a doctor again if given an opportunity, whereas $63.1 \%$ would leave the country to serve abroad in case they get such an opportunity. Conclusion: Most of the doctors were not satisfied with their jobs. Among many factors, dissatisfaction with pay structure seems to be the most significant one. This discontent with their jobs is probably the reason most of them are willing to leave the country and serve abroad. Thus further research on the topic should be conducted to explore and implement strategies to alleviate this dissatisfaction.

Key words: $\quad$ Ayub Teaching Hospital, Income, Job Satisfaction, Medical Doctors, Warr-Cook-Wall Scale.

\section{INTRODUCTION}

Evaluation of job satisfaction in any sector is absolutely essential. This lays the foundation for analysis and resolution of problems that diminishes the efficacy of work. ${ }^{1}$ One of the key element that ensures growth and development at both, individual and organizational level is job contentment. $^{2}$ Job satisfaction also promotes personal physical and psychological health. ${ }^{3}$ This leads to less absenteeism, higher productivity and more organizational discipline. ${ }^{4}$ Whereas discontent is a cause of stress, leading to mental and physical health issues. Healthcare systems are no different in this aspect, and doctors are considered to be at higher risk of stress and its health related consequences. ${ }^{5}$ Comparative analysis done previously has depicted the fact that prevalence of alcohol dependence ${ }^{6}$ and mental health problems ${ }^{7-9}$ is higher in doctors than in other comparable classes. Autonomy, higher pay scales and provision of better healthcare services are definitely factors of contentment among doctors. Whereas overburden and longer working hours are identified factors of dissatisfaction, leading to aforementioned outcomes. ${ }^{5,10}$ This can lead to serious problems like suicidal tendencies. ${ }^{11}$ On the other hand, job satisfaction of healthcare providers is also a determinant of patient's satisfaction, leading to better patient care, compliance and outcome. ${ }^{12,13}$
1. MBBS, MRCS, Resident Officer Orthopedics, Ayub Teaching Hospital, Abbottabad. 2. MBBS, House Officer Surgery, Ayub Teaching Hospital, Abbottabad.

3. MBBS, FCPS, Resident Neurosurgery, Ayub Teaching Hospital, Abbottabad.

4. MBBS, Medical Officer Pediatric, Ayub Teaching Hospital, Abbottabad.

5. MBBS, FCPS, Medical Officer Orthopedics, Ayub Teaching Hospital, Abbottabad.

6. MBBS, FCPS, Assistant Professor Histopathology, Ayub Teaching Hospital, Abbottabad

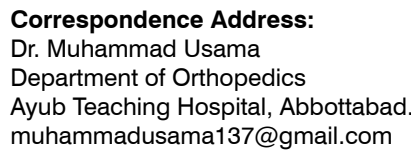

Correspondence Address:

Dr. Muhammad Usama

Department of Orthopedics

Ayub Teaching Hospital, Abbottabad. muhammadusama137@gmail.com

Article received on:

$22 / 02 / 2021$

Accepted for publication: 
Hence understanding determinants of physician's career satisfaction and associated changes that can improve contentment are significant in various aspects. Firstly dissatisfied healthcare professionals not only leave the profession themselves, but also discourage talented individuals from opting the field. Secondly quality of care provided is directly proportional to doctor's satisfaction level. These problems lead to high turnover of employees at healthcare facilities leading to financial loses and patient dissatisfaction. Thus directly or indirectly affecting the organizations associated with healthcare facilities. ${ }^{14}$

Hence the objectives of this research are:

1. To find out satisfaction level of doctors working at Ayub Teaching Hospital Abbottabad, especially after the implementation MTI act.

2. To assess the correlation between job satisfaction and various recognized factors with use of a standardized tool: Warr-Cook-Wall Job Satisfaction Scale.

3. To determine the relation of satisfaction with various professional and sociodemographic characters of respondents, as well as organization dependent factors like complimentary services etc.

\section{MATERIAL \& METHODS}

A cross-sectional survey was conducted at Ayub Teaching Hospital, Abbottabad. It is an MTI based tertiary care hospital and is the largest health care facility of Northern Pakistan. At present it is a center of both undergraduate and postgraduate studies in various disciplines of Medicine and Surgery. In our study all the medical doctors serving the aforementioned institute for more than three months were invited to participate by filling an online survey form developed on Google Forms. Pretesting of this questionnaire was done on 15 doctors working at various designations. These were then not considered in the actual study.

For data collection the questionnaires were distributed during the first two weeks of December, 2019 over various online platforms. Each respondent was allowed to fill a single form and had to check the consent statement before proceeding to the research questions. Responses received till the end of December 2019 were considered. During this period 176 doctors submitted dully filled forms with checked in consent statement. The online form had two sections. First section collected information regarding various sociodemographic and professional characteristics. While section two was composed of a standardized tool; WarrCook-Wall Job satisfaction Scale (Table-I). It is a 10 itemed scale that gathers respondent's insight regarding 10 key features related to their job. ${ }^{15}$ Respondents submitted their opinion on a Likert scale from 1 to 7 . On the scale 1 stood for extreme dissatisfaction and 7 referred to extreme satisfaction. Whereas, for the numbers in between the greater the number more is the level of satisfaction, with number "4" considered as "not sure".

Statistical analysis was done using SPSS (Statistical Package for Social Sciences) 23 for Windows 10. Categorical data was presented in percentages and continuous data with measures of central tendencies. Relationship between continuous variables and job satisfaction score was determined by Pearson's Correlational Analysis. Student's t-test and ANOVA were applied for the categorical variables.
1. Physical working conditions
2. Colleagues and fellow workers
3. Recognition for your work
4. Amount of responsibility
5. Hours of work
6. Income
7. Opportunity to use your abilities
8. Amount of variety at work
9. Freedom of working method
10. Overall job satisfaction

Table-I Warr-Cook-Wall scale.

\section{RESULTS}

A total of 176 doctors working at Ayub Teaching Hospital Abbottabad filled and submitted the research questionnaire. Of these 100 (56.8\%) were male and 76 (43.2\%) were females. Mean age was 
$29.07 \pm 5.87 .65 .3 \%$ of these were bachelors while the rest $(34.7 \%)$ were married. More than half of the sample (63.1\%) were serving the institute for last 1-5 years and the most of the respondents (i-e 52.8\%) were Postgraduate Residents. This translates into majority (79.5\%) being temporary employee and $92.6 \%$ of the total not having private practice. Average weekly working hours were 46.51 \pm 17.15 , whereas each doctor did around $3.97 \pm 3.19$ nights each month. Monthly salary was PKR 75,815 \pm 37425.78 . Most common rating response for both institutional housing and food services was average (31.3\% and $25.6 \%$, respectively). $71 \%$ of the doctors would like to be a doctor again if given an opportunity, whereas $63.1 \%$ would leave the country to serve abroad in case they get such an opportunity (Table-II).

Satisfaction scores for each of the criteria in the 10-item Warr-Cook-Wall scale are presented in Table-III. On the scale 1 stands for extreme dissatisfaction and 7 refers to extreme satisfaction, where for the numbers in between the greater the number more is the level of satisfaction, with "4" considered as "not sure". So all those with score greater than 4 for any single item or total score greater than 40 are considered satisfied. Total Job Satisfaction Score (JSS) of sample was $37.56 \pm 13.35$, which is below the neutral level, showing overall discontent and only 72 (40.9\%) respondents were actually satisfied with their jobs. Whereas for individual items results higher than four were recorded for only two aspects i-e "Colleagues \& fellow workers" and "Amount of Responsibility". Average satisfaction score for "Colleagues \& fellow workers" was 4.28 1.72 and that for "Amount of Responsibility" was $4.13 \pm 1.76$. As a group, sample population was not satisfied with any of the other criteria. Lowest score of $3.26 \pm 1.79$ was noted for "Income".

Pearson's correlational analysis is summed up in Table-IV. Weak positive but statistically insignificant relationship of job satisfaction score is evident with age $(r=0.095 . p=0.209)$ and monthly night shifts $(r=0.04, p=0.596)$. Working hours have negative but insignificant relationship with satisfaction level $(r=0.04, p=0.596)$. Only statistically significant relationship found was that of salary with job satisfaction score $(r=0.151$, $p=0.045)$.

Student's t-test analysis results are given in Table-V. Inferential analysis found that females were slightly more satisfied with mean score of $39.42 \pm 1.5$, in comparison to $36.16 \pm 1.33$ of males but insignificant $(p=0.109)$. Married doctors scored slightly higher $(37.68 \pm 13.57)$ than bachelors $(37.5 \pm 13.28)$ with $p=0.931$. Doctors who were primarily involved in teaching (academics) were significantly more satisfied $(44.86 \pm 14.71$ with $p=0.006)$ in comparison to the clinicians $(36.52 \pm 12.86)$. People with permanent job had a mean score of $42.02 \pm 13.84$ in comparison to $36.42 \pm 13.02$ of temporary employee with $p=0.024$, that shows a significant difference. Physicians that had private practice scored slightly higher than their counterpart $(p=0.705)$.

One way ANOVA was applied for categorical variables with more than two subgroups. For duration of service at the institute highest score of 43 was noted for those who have served for more than 20 years but it was not significantly higher than others $(p=0.153)$. Employees with highest academic degree of M.Phil were the most content but analysis showed that the differences among subgroups were insignificant $(p=0.088)$. Analysis for department categories and designation were significant $(p=0.012 \& p=0.005$ respectively) where those working in Basic Medical Sciences departments most pleased with their job (mean score 47.77) and those on Professors posts were most satisfied (mean $=53.25$ ). Views regarding housing and food facilities were also recorded and comparative analysis was performed. Those who rated housing services as good were significantly more gratified (mean $=46.21, p=0.001$ ) while no statistically significant difference was noted in food services response categories. Doctors who would prefer to be in the same profession again were significantly more satisfied (means score $=39.72, p=0001)$. While ANOVA results didn't notice any significant difference among the subcategories made on the basis of whether or not respondent will avail a foreign opportunity. 


\begin{tabular}{|l|c|c|c|}
\hline \multicolumn{1}{|c|}{ Variable } & Subgroups & Frequency & Percentage \\
\hline & Not Availed & 43 & 24.4 \\
\hline & Poor & 31 & 17.6 \\
& Below Average & 28 & 15.9 \\
& Average & 55 & 31.3 \\
& Good & 19 & 10.8 \\
\hline & Excellent & 0 & 0 \\
\hline Food Services & Not Availed & 30 & 17 \\
& Poor & 43 & 24.4 \\
& Below Average & 43 & 24.4 \\
& Average & 45 & 25.6 \\
\hline & Good & 14 & 8 \\
\hline Choice for Profession & Excellent & 1 & 0.6 \\
\hline & Yes & 125 & 71 \\
\hline Availing Foreign & No & 20 & 11.4 \\
Opportunity & Maybe & 31 & 17.6 \\
\hline
\end{tabular}

Table-II. Distribution of responses for rating institutional services and career choices.

\begin{tabular}{|l|c|c|c|}
\hline & Variable & Pearson Correlation Coefficient & P-Value \\
\hline \multirow{3}{*}{$\begin{array}{l}\text { Overall Job Satisfaction } \\
\text { Score }\end{array}$} & Age (years) & 0.095 & 0.209 \\
\cline { 2 - 4 } & Weekly working hours & -0.065 & 0.39 \\
\cline { 2 - 4 } & Monthly night shifts & 0.04 & 0.596 \\
\cline { 2 - 3 } & Monthly salary & 0.151 & $0.045^{\star}$ \\
\hline
\end{tabular}

Table-IV. Pearson's correlational analysis if various continuous variables with total job satisfaction score. * Statistically significant result

\begin{tabular}{|c|c|c|c|c|c|c|c|}
\hline & \multicolumn{2}{|c|}{ Parameter } & \multirow{2}{*}{$\begin{array}{c}\text { No } \\
100 \\
76\end{array}$} & \multirow{2}{*}{$\begin{array}{c}\begin{array}{c}\text { Mean Score } \\
\pm \text { SD }\end{array} \\
36.16 \pm 1.33 \\
39.42 \pm 1.50\end{array}$} & \multirow{2}{*}{$\begin{array}{l}\text { T-Value } \\
-1.612\end{array}$} & \multirow{2}{*}{$\begin{array}{r}\text { df } \\
174\end{array}$} & \multirow{2}{*}{$\begin{array}{r}\text { P-Value } \\
0.109\end{array}$} \\
\hline \multirow{5}{*}{$\begin{array}{l}\text { Overall Job } \\
\text { Satisfaction } \\
\text { Score }\end{array}$} & Gender & $\begin{array}{l}\text { Male } \\
\text { Female }\end{array}$ & & & & & \\
\hline & $\begin{array}{l}\text { Marital } \\
\text { Status }\end{array}$ & $\begin{array}{l}\text { Single } \\
\text { Married }\end{array}$ & $\begin{array}{c}115 \\
61\end{array}$ & $\begin{array}{l}37.50 \pm 13.28 \\
37.68 \pm 13.57\end{array}$ & -0.087 & 174 & 0.931 \\
\hline & $\begin{array}{l}\text { Nature of } \\
\text { Work }\end{array}$ & $\begin{array}{l}\text { Academic } \\
\text { Clinical }\end{array}$ & $\begin{array}{c}22 \\
154\end{array}$ & $\begin{array}{l}44.86 \pm 14.71 \\
36.52 \pm 12.86\end{array}$ & 2.79 & 174 & $0.006^{*}$ \\
\hline & Job Type & $\begin{array}{l}\text { Temporary } \\
\text { Permanent }\end{array}$ & $\begin{array}{c}140 \\
36\end{array}$ & $\begin{array}{l}36.42 \pm 13.02 \\
42.02 \pm 13.84\end{array}$ & -2.27 & 174 & $0.024^{*}$ \\
\hline & $\begin{array}{l}\text { Private } \\
\text { Practice }\end{array}$ & $\begin{array}{l}\text { Yes } \\
\text { No }\end{array}$ & $\begin{array}{c}13 \\
163\end{array}$ & $\begin{array}{l}38.92 \pm 14.54 \\
37.46 \pm 13.29\end{array}$ & 0.379 & 174 & 0.705 \\
\hline
\end{tabular}

\section{DISCUSSION}

Majority of the doctors working at Ayub Teaching Hospital (ATH) were not satisfied with their jobs. According to the scale used only $40.9 \%$ (72) individuals were generally content. This score is reasonably lower than the one noted by Sultana A et al. earlier in $2009 .{ }^{16}$ Though such high results were also noted in India and Japan (69.5\% and $60 \%$ respectively) $)^{17,18}$, but various researchers from Middle East published lower rates. In Kuwait Alqasabi FB et al. concluded that only $50 \%$ of the physicians were satisfied ${ }^{19}$, while satisfaction level as low as $38.7 \%$ was calculated in Egypt. ${ }^{20}$ 


\begin{tabular}{|c|c|c|c|c|c|c|}
\hline & Variable & $\begin{array}{l}\text { Categories (mean total job } \\
\text { satisfaction score) } ¥\end{array}$ & df1 & df2 & $\mathbf{F}$ & P-Value \\
\hline \multirow{8}{*}{$\begin{array}{l}\text { Overall Job } \\
\text { Satisfaction } \\
\text { Score }\end{array}$} & $\begin{array}{l}\text { Years of } \\
\text { service } \\
\text { categories }\end{array}$ & $\begin{array}{l}<1(41.22) \\
1-5(35.78) \\
5-10(36.0) \\
10-20(41.25) \\
>20(43.0)\end{array}$ & 4 & 171 & 1.67 & 0.153 \\
\hline & $\begin{array}{l}\text { Highest } \\
\text { Academic } \\
\text { degree }\end{array}$ & $\begin{array}{l}\text { MBBS }(37.34) \\
\text { Diploma }(43.33) \\
\text { MCPS }(31.75) \\
\text { M.Phil (53.6) } \\
\text { FCPS (33.5) } \\
\text { FRCS (38.0) }\end{array}$ & 4 & 170 & 1.952 & 0.088 \\
\hline & $\begin{array}{l}\text { Department } \\
\text { categories }\end{array}$ & $\begin{array}{l}\text { General Surgery (38.43) } \\
\text { Surgery Specialities (36.25) } \\
\text { General Medicine (35.45) } \\
\text { Medical Specialities (39.74) } \\
\text { Gyne \& Obs (37.28) } \\
\text { Pediatrics (32.34) } \\
\text { Basic Medical Sciences (47.77) }\end{array}$ & 6 & 169 & 2.84 & $0.012^{*}$ \\
\hline & Designation & $\begin{array}{l}\text { House Officer (34.93) } \\
\text { Medical Officer (42.27) } \\
\text { Training Medical Officer (36.25) } \\
\text { Lecturer (47.71) } \\
\text { Registrar (33.0) } \\
\text { Assistant/Associate Professor } \\
\text { (37.83) } \\
\text { Professor (53.25) }\end{array}$ & 6 & 169 & 3.248 & $0.005^{\star}$ \\
\hline & $\begin{array}{l}\text { Housing } \\
\text { Services } \\
\text { Satisfaction } \\
\text { levels }\end{array}$ & $\begin{array}{l}\text { Not Availed (36.5) } \\
\text { Poor (30.0) } \\
\text { Below Average (39.1) } \\
\text { Average (38.8) } \\
\text { Good (46.21) }\end{array}$ & 4 & 171 & 5.231 & $0.001^{*}$ \\
\hline & $\begin{array}{l}\text { Food } \\
\text { Services } \\
\text { Satisfaction } \\
\text { levels }\end{array}$ & $\begin{array}{l}\text { Not Availed (37.86) } \\
\text { Poor (33.74) } \\
\text { Below Average (37.34) } \\
\text { Average (39.26) } \\
\text { Good (44.14) } \\
\text { Excellent (34.0) }\end{array}$ & 5 & 170 & 1.575 & 0.17 \\
\hline & $\begin{array}{l}\text { Medicine as } \\
\text { profession of } \\
\text { choice again }\end{array}$ & $\begin{array}{l}\text { Yes }(39.72) \\
\text { No }(29.3) \\
\text { Maybe (34.22) }\end{array}$ & 2 & 173 & 6.862 & $0.001^{*}$ \\
\hline & $\begin{array}{l}\text { Availing } \\
\text { Foreign } \\
\text { Opportunity }\end{array}$ & $\begin{array}{l}\text { Yes }(36.35) \\
\text { No }(35.4) \\
\text { Maybe }(41.81)\end{array}$ & 2 & 173 & 2.99 & 0.053 \\
\hline
\end{tabular}

Hence job contentment level of our doctors lies towards the lower side of previously noted figures and it is concerning because it is noticeably lower than the level noted previously in Rawalpindi Medical College and Teaching
Hospitals, Pakistan. ${ }^{16}$ Higher satisfaction levels noted in this study could be because the aforementioned institutes of Rawalpindi are more developed thus may be providing better facilities to their employee. The fact that such services 
apart from work itself, also affects employees' gratitude towards the institute can be justified by the views of the participants on food and housing services at ATH. Most common rating response for both the aforementioned services were average. Alongside this, those who rated housing services as good had significantly higher satisfaction score (mean $=46.21, p=0.001$ ) than the other subgroups. For each individual criterion of the scale, study population was only satisfied with their "Colleagues \& fellow workers" and "Amount of Responsibility". Sultana A et al. also noted that $78.7 \%$ of healthcare providers were satisfied with the behavior of their colleagues. ${ }^{16}$ In such scenario it is appreciable that in a working environment where interpersonal relations are good, responsibility gets distributed equally and no single person is affected by workload. Hence these two aspects of job are interlinked, so the results of both are promising.

In contrast to the above, lowest contentment scores were appreciated for "income" and these are not different from previous publications on the topic in Pakistan. Shakir SS et al. stated that most of the doctors were not happy with their service structure and pay scales. ${ }^{21}$ Our analysis also found out that only statistically significant relationship that job satisfaction score had was that with respondents' salary. A weak but positive relation was noted $(r=0.151, p=0.045)$. This impact of pay on contentment levels could be related to three other statistically significant findings of this project. First, doctors that were primarily involved in teaching undergraduates were more satisfied with their work in comparison to clinicians. Possibly because their job is easier, as they have less working hours and no night shifts. At the same time they are paid better than those in clinical fields and are usually permanent employees. Second, professors were found more content. They too have relatively easy working hours, are paid more and have permanent jobs. Third, all the permanent employees were more gratified than those working on contract. Here too, this can be an effect of higher salaries that this subcategory gets.

Sultana A et al. also concluded that basic sciences employees scored higher at job satisfaction scale and were happier with their pay structure in comparison to clinical sciences doctors. ${ }^{16}$ Shakir SS and his team too noted that pay and designation have statistically significant positive correlation with job contentment, thus approving our results. ${ }^{21}$ Despite the fact that most doctors were dissatisfied, $71 \%$ of the respondents were of the view that if they were given an opportunity to decide their profession again, they will still go for medicine. This subgroup was significantly more satisfied too according to the Warr-CookWall scale $(p=0001)$. Possibly because they think that doctors are more privileged than other communities in our society. But at the same time majority $(63.1 \%)$ of the doctors working at ATH were willing to go abroad, if an opportunity arrives.

\section{CONCLUSION}

In conclusion, most of the doctors working at Ayub Teaching Hospital Abbottabad were not satisfied with their jobs. Among various reasons, pay structure seems to be the most important one. This dissatisfaction is probably the reason most of these individuals were willing to leave this country and serve abroad. Thus immediate steps should be taken to resolve issues that are cause of this discontent. This research invites further study on the topic to explore and implement strategies to alleviate this dissatisfaction, otherwise these talented professionals might start leaving the country in search of better opportunities abroad.

Copyright $(11$ June, 2021.

\section{REFERENCES}

1. Powell L. Conducting employee satisfaction surveys hospital. Idaho: Mountain States Group, Inc. 2001.

2. Mann E, Jefferson K. Retaining staff: Using turnover indices and surveys. J Nurs Admin. 1988; 18:17-23.

3. Hendrix W. Job and personal factors related to job stress and risk of coronary artery disease. Psychol Reports. 1989; 65:1136-8.

4. Lease SH. Work attitudes and outcomes. J Vocational Behav. 1998; 53(2):154-83.

5. Burbeck R, Coomber S, Robinson SM, Todd C. Occupational stress in consultants in accident and emergency medicine: A national survey of levels of stress at work. Emerg Med J. 2002; 19:234-38. 
6. Murray RM. Alcoholism amongst male doctors in Scotland. Lancet. 1976; 729-33.

7. Blenkin H, Deary IJ, Sdler A, Agius R. Stress in NHS consultants (Letter). BMJ. 1996; 310:534.

8. Ramirez AJ, Graham J, Richards MA, Cull A, Gregory WM. Mental health of hospital consultants: The effects of stress and satisfaction at work. Lancet. 1996; 347:724-8.

9. Kapur N, Borrill C, Stride C. Psychological morbidity and job satisfaction in hospital consultants and junior house officers: Multicentre, cross sectional survey. BMJ. 1998; 317:511-12.

10. Appleton K, House A, Dowell A. A survey of job satisfaction, sources of stress and psychological symptoms among general practitioners in Leeds. Bir J Gen Pract. 1998; 48:1049-63.

11. Lindeman S, Laara $E$, Hakko $H$, Lonnqvist J. A systematic review on gender- specific suicidal mortality in medical doctors. $\mathrm{Br} \mathrm{J}$ Psychiatry. 1996; 168:274-9.

12. Bartell J, Smith M. Physician professionalism and organizational efforts to improve quality: A systems perspective. WMJ. 2004; 103:66-70.

13. Haas J, Cook E, Puopolo A, et al. Is the professional satisfaction of general internists associated with patient satisfaction? J Gen Intern Med. 2000; 15(2):122-8.
14. Fletcher SJ. Minority physician job satisfaction: An analysis of extrinsically-controlled organizational factors. A master of arts thesis in the Nicholson school of communication in the college of arts and sciences. University of Central Florida Orlando: Florida, 2005; p.16.

15. Hills D, Joyce C, Humphreys J. Validation of a job satisfaction scale in Australian clinical medical workforce. Eval Health Prof. 2012; 35(1):47-76.

16. Sultana $A$, Riaz $R$, Hayat $M$, et al. Level of job satisfaction in doctors. J Rawalpindi Med Coll. 2009; 13(2):95-7.

17. Madaan N. Job satisfaction among doctors in a Tertiary Care Teaching Hospital. J K Science. 2008; 10(2):81-3.

18. Wada K, Arimatsu M, Higashi T, et al. Physician job satisfaction and working conditions in Japan. J Occup Health. 2009; 51:261-6.

19. Alsaqabi FB, Aldousari $A$, Ismail $A E$, et al. Job satisfaction among physicians in Al-Sabah Hospital, Kuwait. Bull Alex Fac Med. 2010; 46(2):101-8.

20. Abdel-Rahman AG, Abdel-Halim A, Allam MF, et al. Low job satisfaction among physicians in Egypt. TSK Koruyucu Hekimlik Bülteni. 2008; 7(2):91-6.

21. Shakir S, Ghazali A, Shah IA, Zaidi SAA, Tahir MH. Job satisfaction among doctors working at teaching hospital of Bahawalpur, Pakistan. J Ayub Med Coll Abbottabad. 2007; 19(3):42-5.

\begin{tabular}{|c|l|l|l|}
\hline \multicolumn{3}{|c|}{ AUTHORSHIP AND CONTRIBUTION DECLARATION } \\
\hline No. & \multicolumn{1}{|c|}{ Author(s) Full Name } & \multicolumn{1}{|c|}{ Contribution to the paper } \\
\hline 1 & Muhammad Usama & $\begin{array}{l}\text { Jointly proposed study, analysis } \\
\text { data \& prepared the draft. } \\
\text { Jointly proposed study, analysis } \\
\text { data \& prepared the draft. } \\
\text { Jointly proposed study, analysis } \\
\text { data \& prepared the draft. } \\
\text { Contributed to study design, } \\
\text { data collection \& draft review. } \\
\text { Contributed to study design, } \\
\text { data collection \& draft review. } \\
\text { Contributed to study design, } \\
\text { data collection \& draft review. }\end{array}$ \\
\hline 5 & Umair Toqueer & Attiya Nasir Siddique \\
\hline 4 & Sana Khan & Muhammad Basharat & \\
\hline 6 & Anila Riyaz &
\end{tabular}

